tions cannot be ruled out. The next two decades would lay the foundations, on which higher education would evolve in the developing world for the many decades to come after.

\section{Massification and the Global Knowledge Economy: The Continuing Contradiction}

\section{Philip G. Altbach}

Philip G. Altbach is research professor and director of the Center for International Higher Education at Boston College.E-mail: altbach@ bc.edu.

Two of the challenges of the past half century will continue to be among the key drivers of higher education realities, for the coming several decades-providing greater access to tertiary education and sustaining research centers that will contribute and disseminate the knowledge essential to modern societies. These two key forces are contradictory and pull academe in different directions.

Global enrollments now stand at more than 150 million, having doubled in just a few decades, and it is likely that there will be another 100 million added by 2020 . A significant part of that growth will be in just two countriesChina and India. Providing postsecondary education to larger segments of the population is not only necessary, as increasingly sophisticated economies demand higher levels of training, but as key to social mobility and more attractive employment.

Massification has placed great stress on government finances and has led to a rapidly growing private higher education sector. Shortages of qualified academic staff and newer, underresourced institutions often accompany this rapid expansion; as a consequence, overall quality has declined, in some countries dramatically. Yet, many millions have now obtained academic qualifications and in general achieved better lives as a result.

At the same time, the global knowledge economy requires more sophisticated and top-quality higher education to educate graduates who are capable of participating in the globalized 2Ist century economy. Universities must support research in the pursuit of new scientific endeavors, as well as serve as repositories of knowledge in all disciplines. Research universities, the engines of the global knowledge economy, are complex institutions, and are the foci of international networks. Although powerful, they are also fragile institutions, requiring autonomy, shared governance, and academic freedom. These universities are expensive and complex. They are, with few exceptions, public institutions requiring unqualified state support; these are the worldclass universities that dominate the rankings. Yet, it is often difficult for governments to understand these expensive yet necessary universities.

There is a seeming dichotomy between the necessity of providing postsecondary education for large numbers of students and, at the same time, supporting elite research universities. Yet, both are necessary parts of a differentiated academic system, and both serve important functions in the global knowledge economy-one to provide the increasingly sophisticated needs of the economy, as well as the general knowledge to function as effective citizens, and the other to educate the most able students, to provide both basic and applied research. Both are absolutely essential to a successful national economy, as well.

Supporting these two-core objectives is a necessity for the coming decades. Yet, there are signs in many countries, mass "demand absorbing" higher education is proving too heavy a burden for governments. Also, a growing private sector, often for-profit, tends to fill the gap, often providing lower-quality education. At the same time, expensive and largely public research universities are confronting alarming budget cuts. A key challenge is to ensure that both key aspects of higher education are appropriately supported.

\section{The Crisis of the Public Mis- sion in Higher Education}

\section{JORGE BALÁn}

Jorge Balán is senior research scholar, Columbia University. E-mail: jb3369@columbia.edu.

The major challenge for higher education worldwide is to strengthen and revitalize its commitment to the public mission, as a response to the overall-per-student decline in public funding, the shifting rationale, strategies, and instruments that governments subsidize and regulate higher education, and to cope with changes in student demand and in the society at large.

State ownership and funding of public institutions are often and erroneously identified with a public mission in countries where these institutions enjoy considerable prestige, autonomy, and political clout in shaping public policy. Administrators, faculty, and students are often critical of the 